DOI 10.31558/2519-2949.2021.3.3

УДК $323.15+316.354 .4$

ORCID ID: https://orcid.org/0000-0002-7719-7791

Матвієнків С. М., Прикарпатський національний університет імені Василя Стефаника

\title{
ГРОМАДСЬКІ ОРГАНІЗАЦІЇ НАЦІОНАЛЬНИХ МЕНШИН ПРИКАРПАТТЯ В СУСПІЛЬНО-ПОЛІТИЧНОМУ ЖИТТІ РЕГІОНУ
}

У статті приділено увагу ролі національних меншин у процесах нащіональної консолідації, збагаченні начіональної культури та становленні громадянського суспільства в Украӥні. Виконуючи роль соціальних посередників між групами виразників різних інтересів і урядовими структурами, між громадянським суспільством і державою, вони спрямовують свою діяльність на розвиток міжнаціональних відносин, відродження національних культур, задоволення свойх духовних запитів. Для України, як і для будь-якої поліетнічної держави, питання національних меншин є актуальним $i$ потребує постійного дослідження.

У статті проаналізовано поняття «національні меншини», досліджено діяльність громадських об’єднань національних меншин на території Івано-Франківської області, виявлено їх роль у суспільно-політичному житті регіону та доведено, що громадські організації національних меншин виступають переважно засобом збереження своєї самобутності та ідентифікаиії і тісно співпрачюють з місиевими органами виконавчої влади та органами місцевого самоврядування. Загалом, Прикарпаття не належить до потенційно конфліктних регіонів Украйни й максимально наближене до середньостатистичної області краӥни. Досліджено, щяо на стан створення $i$ діяльність громадських об'єднань національних меншин впливає передусім фінансова підтримка як з боку держав, які є їхніми історичними батьківщинами, так і держав, на території яких вони постійно проживають. Зроблено висновки про те, щьо найактивнішими серед національних меншин Прикарпаття у громадському житті є поляки, угориі та євреї. Решта етнічних спільнот не створили свойх громадських об'єднань чи через малочисленність, чи через відсутність потреби у такій самоорганізачії.

Ключові слова: національні меншини, громадські організації, громадянське суспільство, ідентичність, Прикарпаття.

Одним із найвагоміших здобутків Української держави, після отримання нею державної незалежності, є стабільність міжнаціональних відносин, відсутність гострих широкомасштабних конфліктів та протистоянь. Подальше формування мирного поліетнічного суспільства потребує поєднання процесу етнічної самоідентифікації та формування нації у розумінні її як громадянського співтовариства. Значне місце у цьому процесі посідають громадські організації національних меншин. Громадські об'єднання як інститути громадянського суспільства виступають єднальною ланкою між суспільством і державною владою, вони $є$ формою інституціоналізації розмаїтих суспільних інтересів та їх захисту. В поліетнічних суспільствах вони можуть ставати тими механізмами, які формують, захищають та реалізують інтереси збереження етнічної самобутності [6, с.33].

Національна меншина - це чисельно менша, відмінна за своїми етнічними ознаками від основної маси населення, група громадян даної країни, глибоко інтегрованих в її суспільне життя, що мають тривалу традицію проживання на ії території й прагнуть добровільно зберігати та розвивати свою етнічну, культурну, мовну і релігійну самобутність [7, с.615].

Національні меншини України - це громадяни України, які проживають на території України і які не $\epsilon$ етнічними українцями та за чисельністю перебувають у меншості, відрізняючись від етнічних українців своєю мовою, культурою і традиціями, виявляючи національне самоусвідомлення та спільності між собою. Вони є елементом суспільного ладу, а отже, усіх основних систем: політичної, економічної, соціальної, культурної та інших [1, с.76].

Для присутності у сучасному українському просторі та забезпечення і збереження своїх культурних особливостей і традицій національні меншини утворюють власні громадські об'єднання, 
які організовують здебільшого культурно-мистецькі проєкти і події, беруть участь у суспільнополітичному житті регіону. Варто зазначити, що серед державних та суспільних інститутів сучасної України громадським організаціям довіряють 53\% населення [8]. Це досить значний показник, особливо якщо враховувати низький рівень довіри населення до інших інституцій, особливо державних структур. Високий рівень участі громадян у діяльності громадських організацій є одним 3 основних показників розвитку громадянського суспільства та громадської активності населення.

Мета статті - проаналізувати сучасні громадські організації національних меншин Прикарпаття в процесі формування громадянського суспільства в Україні, зокрема його етнополітичного виміру, оскільки в поліетнічних суспільствах вони можуть ставати тими механізмами, які формують, захищають та реалізують інтереси збереження етнічної самобутності.

Проблеми прав та свобод національних меншин досліджували О. Биков, В. Євтух, О. Картунов, І. Кресіна, Л. Лойко, О. Майборода, В. Махманович, Н. Панчук, О. Рафальський, П. Надолішній, В. Нікітюк, М. Пірен, В. Скуратівський, В. Трощинський та інші. Етнополітичній суб'єктності громадських організацій етнічних меншин України присвячено дисертаційне дослідження Л. Лойко. Конституційно-правовий статус національних меншин в Україні досліджував О. Биков, а етнічні спільноти у суспільно-політичному просторі регіону Л. Ковач. Питання сутності та типологізації громадських організацій розглядали: В. Бех, О. Ващук, Л. Войтова, А. Івченко, Л. Усаченко, В. Степаненко та інші, а роль громадських організацій у становленні та розвитку громадянського суспільства - В. Коваленко, А. Лясота, А. Матвійчук, М. Шевченко, О. Юлдашев та інші.

Одним із механізмів участі національних меншин у суспільно-політичному житті та розвитку своєї культури, мови, самобутності є забезпечення та сприяння діяльності громадських організацій у формуванні та реалізації етнополітики не тільки на державному, а й на регіональному рівні. Це можна прослідкувати на прикладі Івано-Франківської області, особливістю етнічного складу населення якої $є$ багатонаціональність і багатокультурність.

У національному складі населення області за переписом 2001 року переважали українці, яких нараховувалося 1371,2 тис. осіб або 97,5 \% від загальної кількості населення (1409,8 тис.). Тут також проживають представники понад 90 національностей і народностей: росіяни - 24,9 тис. (їх кількість порівняно з переписом 1989 року зменшилась на 56,3 \% і зараз складає менше 1\% від загальної кількості росіян, які проживають на території України), поляки - 1,9 тис., білоруси - 1,5 тис., молдовани - 557, євреї - 362, вірмени - 282, німці - 221, угорці - 124, та ін. [10].

Росіяни, поляки, євреї, німці, угорці активно присутні у громадському секторі Івано-Франківської області. У регіоні зареєстровано і діють 38 організацій національних меншин, 3 них - 20 мають обласний статус, 9 - міський, 7 - районний та 17 громадських організацій етнографічних груп українців, з яких 2 мають Всеукраїнський статус, 3 - обласний, 12 - районний. Так, із загальної кількості зареєстрованих громадських організацій національних меншин на Прикарпатті, найчисельнішою громадою $є$ поляки - 6 організацій, а німці, євреї, росіяни, угорці мають по одній організації.

Найактивніше серед національних меншин беруть участь у громадському житті області поляки. Перепис населення у 2001 році показав, що в місті Івано-Франківську мешкає близько двох тисяч етнічних поляків (на 250 тисяч мешканців). Польська спільнота найчисельніша серед інших меншин і досить активна. У місті працюють такі громадські організації: обласне товариство польської культури імені Францішка Карпінського (приблизно дві сотні учасників), товариство польської культури «Пшиязнь» (опікується цвинтарем у Чорному лісі), польсько-українська молодіжна організація «Млоди Станіславув» (розвиває стосунки між молоддю Польщі і України: роблять спільні тренінги, майстер-класи, навчання та поїздки для обміну досвідом), «Родина польська і Свропа» (допомагає відновлювати втрачені родинні зв'язки), Польське товариство імені Анджея Потоцького (активність його членів $є$ періодичною), Центр польської культури та європейського діалогу (є платформою для взаємодії всіх польських організацій). Загалом, у статутах цих громадських організацій прописана підтримка і популяризація польської культури, мови, традицій та розвиток українсько-польських стосунків. За останні роки між Україною і Польщею було підписано двосторонні угоди з культурних проєктів. Так, наприклад, створена польсько-українська рада обміну молоді, спільний освітній проєкт - відновлення обсерваторії на горі Піп-Іван Чорногірський, яким займаються Прикарпатський національний та Варшавський університети. Молодь Івано-Франківщини завдяки Центру польської культури та європейського діалогу бере участь у програмах обміну і літніх таборах та має можливість вивчати польську мову на курсах, отримуючи в результаті сертифікат про певний рівень знань. Щороку Центр ініціює конференції, що стосуються історії Франківська-Станіславова та регіону. Вони 
стали важливим майданчиком для спілкування українських і польських науковців і краєзнавців. Щодо стосунків Центру польської культури з міською владою Івано-Франківська, то вони складаються без конфліктів і непорозумінь. У разі потреби Центр завжди отримує підтримку, представники мерії завжди відгукуються на запрошення Центру і беруть участь у його заходах.

Загалом, громадські організації польської національної меншини Прикарпаття позитивно впливають на культурний діалог та співпрацю між сусідніми країнами, сприяючи тим самим політичному примиренню польського та українського народів. Метою їхньої діяльності є «не лише консолідація польської спільноти Прикарпаття, задоволення її національних потреб, але й сприяння плідному багатонаціональнму діалогу, підтримка дружніх польсько-українських відносин» [11]. Сучасна польська меншина Прикарпаття отримала також правові і соціальні гарантії задля забезпечення власних культурних, національних і релігійних потреб, що дозволяє через свої громадські організації брати активну участь у прийнятті управлінських рішень. Так, представником персонального складу Громадської ради при Головному управління ДФС в Івано-Франківській області є голова правління Громадської спілки «Польсько-Український Центр Економічного співробітництва» Петраш О.3 [9].

Власне участь у ній $є$ інструментом координації заходів, пов'язаних із необхідністю проведення консультацій з громадськістю стосовно участі у вирішенні питань соціально-економічного, культурного розвитку області, а також задля розширення ролі інститутів громадянського суспільства в обговоренні інших важливих питань. Сам факт представництва у складі громадської ради дозволяє польським громадським організаціям бути активними учасниками реалізації етнополітики в області, де можуть лобіювати інтереси своєї етнічної спільноти [13].

Однією з не менш активних, але чисельно меншою на Прикарпатті є угорська спільнота - більше сотні осіб. Це люди різних поколінь і різних соціальних верств. Вони старанно бережуть свої традиції, мову, не подібну на інші та одну з найскладніших у світі. Важливою $є$ тісна співпраця між Україною та Угорщиною в культурологічному та соціально-економічному напрямку, зокрема, подальша активізації діяльності безпосередньо на Івано-Франківщині.

У 1997 році Матей Густав заснував Івано-Франківське обласне угорське національно-культурне товариство «Балатон». Організація об’єднала 15-20 місцевих угорців, більшість - народжені вже в Україні. У 2006 році балатонівці відкрили першу в місті школу угорської мови для дітей. У 2014 році відродження угорської громади та школи в Івано-Франківську продовжила етнічна угорка Мирослава Нагорняк. Так, у рамках проведення тижня Угорщини у грудні 2014 року в ІваноФранківську відбулося відкриття нової «Недільної школи» з вивчення угорської мови, яка діє при Прикарпатському національному університеті імені Василя Стефаника. Головною метою створення «Недільної школи» з вивчення угорської мови є задоволення освітніх потреб, повноцінного культурного розвитку, підтримка національних традицій угорців, які проживають на Прикарпатті. Навчання в «Недільній школі» об’єднує різновікові категорії та здійснюється за навчальним планом, узгодженим з Посольством Угорщини в Україні. Угорську мову викладають студенти, які закінчили угорську національну школу i здобувають вищу освіту в Прикарпатському національному університеті імені Василя Стефаника. Зараз у школі діють три групи: діти віком від 6 до 12 років, від 12 до 18 і для дорослих. На щотижневі заняття приходить більше півсотні людей. «Скажу відверто, проблеми з якими стикається громада, сьогодні мають матеріальний характер. Усе робимо власним коштом, - говорить Мирослава Нагорняк. - Є різні програми, які фінансує Угорщина, але всі вони орієнтовані на Закарпатську область. Тому робимо те, що можемо, власними силами намагаємося зберегти культуру, традиції, кухню, мову» [4].

Також у квітні 2014 року в Івано-Франківську відкрили Почесне консульство Угорщини. Його очолив почесний консул Угорщини в місті Івано-Франківську та області Василь Вишиванюк. Ініціатором виступила угорська сторона з метою розширення бізнесу і співпраці між країнами, оскільки Угорщина підтримує територіальну єдність і суверенітет України. Завданням номер один для консульства $\epsilon$ надання гуманітарної допомоги. За час роботи установи тисячі українських дітей (сиріт, соціально незахищених, дітей бійців АТО та ін.) відправили на відпочинок до Угорщини, також роздають гуманітарну допомогу. Разом з громадою консульство працює над впорядкуванням могил угорських солдат [2].

У 2015 році в Івано-Франківську була зареєстрована громадська організація «Угорський культурно-освітній центр», основною метою роботи якої є впровадження просвітницької, наукової, культурної діяльності, що спрямована на поширення та ознайомлення населення краю з культурною спадщиною, традиціями, історією угорського народу та його зв’язків з українським народом. 
Спільнота угорців на Івано-Франківщині приділяе багато уваги для реалізації культурно-освітніх програм та ефективних навчальних проєктів, спілкування, зустрічей для українців етнічного угорського походження. Угорський культурно-освітній центр підтримує та популяризує історію угорців, які проживали на Прикарпатті. Також ГО організовує виставки, відпочинок дітей в Угорщині, участь у культурних заходах і фестивалях області й міста та пошукові роботи з перепоховання угорських воїнів, які загинули в Першій і Другій світових війнах, та багато іншого. Керівницею угорського культурноосвітнього центру в області обрали Мирославу Нагорняк. Висвітлюють свою діяльність у соцмережах, зокрема, мають сторінку у Фейсбуку Magyar Kulturális Oktatási Központ Угорський культурно-освітній центр (https://www.facebook.com/mkokif), де угорською мовою розповідають про події, проєкти, новини 3 життя угорської меншини на Прикарпатті [5].

32017 року у Івано-Франківську зареєстрована ГО «Товариство німців Івано-Франківської області» - об'єднання громадян німецької національності та членів їх сімей. Висвітлюють свою діяльність на сторінці у Фейсбуці «Gesellschaft der Deutschen Ivano-Frankivsk Gebiet» (https://www.facebook.com/Gesellschaft-der-Deutschen-Ivano-Frankivsk-Gebiet-211745699353835/).

Також в місті діє Івано-Франківське обласне відділення міжнародної громадської організації «Товариство німців «Відергебурт».

ГО «Російська община Івано-Франківської області» заснована у 1994 році і перереєстрована у 2016 році. На сучасному етапі (також як і німці) не виявляє активної громадської діяльності через зменшення чисельності: якщо у 1989 році росіян було 4\% від загальної кількості населення області, то в 2001 році тільки $1 \%$.

Щодо євреїв, то зменшення кількості громадян цієї національності загалом в Україні пов'язано із масовим знищенням їх німецькими фашистами в роки Другої світової війни та еміграцією до Ізраїлю й в інші країни. Якщо у 1989 році євреїв було $0,1 \%$ від загальної кількості населення області, то в 2001 році тільки $0,02 \%$. Національна меншина етнічних євреїв Прикарпаття у 2007 році заснувала ГО «Сврейська громада Івано-Франківської області», а в 2016 році - ГО «Єврейська спадщина Рогатина», яка розробляє і провадить проекти із збереження спадщини з метою відновити зв'язок між 400-літньою історією втраченої сьогодні єврейської громади Рогатина з людьми і місцями сучасного українського міста. Мають сторінку У Фейсбуку Rohatyn Jewish Heritage (https://www.facebook.com/RohatynJewishHeritage/), де активно розповідають про таку волонтерську програму.

Варто відзначити, що ЗМІ етноспільнот створюють додаткові можливості для збереження етнічної самобутності. У 2021 році в Івано-Франківську підписали грантовий проєкт вартістю понад 280 тисяч євро «Дослідження та збереження єврейської культурної спадщини на прикордонній території» в рамках Програми транскордонного співробітництва Угорщина - Словаччина - Румунія - Україна 2014-2020. Партнер проєкту - музей м. Марамуреш (румунське місто Сігет)». Проєкт передбачає ремонт водовідведення Синагоги, встановлення зовнішнього освітлення, 10 меморіальних дошок та створення «єврейського» туристичного маршруту». Мета проєкту - покращення співпраці міст ІваноФранківська та Сігет шляхом спільної туристичної капіталізації мультикультурної спадщини, виявлення, збереження та пропаганда єврейської спадщини як важливої частини місцевої історії [3].

Велика частина етнічних спільнот регіону сьогодні поки що не скористалася своїм правом і не створила громадські об'єднання, можливо через малочисленність або через відсутність об'єктивної потреби у такій самоорганізації. Зокрема, на стан створення і діяльність громадських об'єднань національних меншин впливає передусім фінансова підтримка з боку держав, які $\epsilon$ їхніми історичними батьківщинами, держав, на території яких вони постійно проживають, членські внески, спонсорська допомога, а також фінансування проектів та програм національно-культурного відродження міжнародними фондами, акредитованими в Україні [6, с.45].

Таким чином, громадські організації етнічних меншин стають сьогодні важливою складовою українського громадянського суспільства, інтенсивно збагачують його новими формами громадських організацій і новими напрямками діяльності. Їхня поява і розвиток цілком виправдані поліетнічним складом України. Одним із механізмів участі національних меншин в політичному житті країни свого проживання $\epsilon$ забезпечення та сприяння діяльності громадських організацій у формуванні та реалізації етнополітики не тільки на державному, а й на регіональному рівні. Так, питаннями національних меншин сьогодні в Івано-Франківській ОДА займається Управління культури, національностей та релігій (http://www.if.gov.ua/?q=page\&id=19469).

Громадські організації національних меншин на сучасному етапі тісно співпрацюють 3 місцевими органами виконавчої влади та органами місцевого самоврядування, постійно зростає кількість їх культурологічних заходів. Більшість товариств характеризується наявністю 
потенціалу для відродження історії, мови, збереження самобутньої культури, а також досить високим ступенем взаєморозуміння.

У 2021 році Івано-Франківська обласна рада затвердила регіональну цільову програму «Духовне життя». Підпрограмою 2. цієї Програми $є$ підтримка діяльності розвитку культур національних меншин, етнографічних груп українців Івано-Франківської області та об'єднань українців за кордоном. Метою Програми є створення умов щодо задоволення національно-культурних потреб етнічних спільнот та етнографічних груп українців області, зміцнення атмосфери толерантності, міжнаціонального миру в регіоні та налагодження i покращення міжнародних контактів i євроінтеграційних процесів на Прикарпатті; сприяти розвитку етнічної, культурної, мовної та релігійної самобутності національних меншин та етнографічних груп українців, що проживають на території регіону, запобігання проявам розпалювання міжнаціональної та расової ворожнечі в області. Серед очікуваних результатів її виконання є: розвиток дружніх взаємовідносин між представниками різних національностей та народностей, у тому числі за межами області; формування в суспільстві толерантного ставлення до представників різних національностей та етносів; підвищення консолідуючої ролі органів державної влади на шляху гармонізації міжнаціональних взаємовідносин в області; зміцнення атмосфери толерантності та міжнаціонального миру в регіоні; збереження етнічної самобутності національних меншин та етнографічних груп українців регіону; підтримка та проведення різноманітних заходів з ініціативи та за участю представників громадських організацій національних меншин та етнографічних груп українців, які популяризують їхню культуру, в тому числі збереження культурної спадщини національних меншин та етнографічних груп українців [12].

Таким чином, формування та активна діяльність громадських організацій національних меншин служить основою для міжетнічної злагоди, міжкультурної взаємодії та співпраці, сприяє консолідації держави та розбудові громадянського суспільства. Тому подальші дослідження слід спрямовувати, на наш погляд, на поглиблене вивчення тенденцій, чинників розвитку громадських організацій національних меншин. Можна прогнозувати подальше зростання суспільно-політичної ролі етнічних громадських організацій як вагомих суб'єктів етнополітики, а отже грунтових наукових досліджень їх діяльності як важливих інститутів громадянського суспільства.

\section{Бібліографічний список:}

1. Биков О. Конституційно-правовий статус національних меншин в Україні: монографія. Київ: Інт держави і права ім. В.М. Корецького НАН України, 2001. с. 76

2. Василь Вишиванюк очолив Почесне консульство Угорщини в Івано-Франківську.

URL: https://kurs.if.ua/news/vasyl_vyshyvanyuk_ocholyv_pochesne_konsulstvo_ugorshchyny_ v_ivanofrankivsku_10804.html (дата звернення: 06.07.2021).

3.В Івано-Франківську за кошти ЄС створять «єврейський» туристичний маршрут.

URL: https://www.ukrinform.ua/rubric-tourism/3260481-v-ivanofrankivsku-za-kosti-es-stvorat-evrejskij-turisticnijmarsrut.html (дата звернення: 06.07.2021).

4. В Івано-Франківську відкрили "Недільну школу" з вивчення угорської мови.

URL:https://kurs.if.ua/news/v_ivanofrankivsku_vidkryly_nedilnu_shkolu_z_vyvchennya_ugorskoi_movy_10849.htm 1/ (дата звернення: 08.07.2021).

5.B Івано-Франківську відкрили угорський культурно-освітній центр. URL: https://mi100.info/2020/01/24/ v-ivano-frankivsku-vidkryly-ugorskyj-kulturno-osvitnij-tsentr (дата звернення: 09.07.2021).

6.Ковач Л. Етнічні спільноти Донбасу у суспільно-політичному просторі регіону/ Наукові записки Інституту політичних і етнонаціональних досліджень ім. І.Ф.Кураса НАН України. 2013 / 5 (67). с. 33-45

7.Ковбасюк Ю., Трощинський В. Соціальна і гуманітарна політика: підручник. Київ: НАДУ, 2016. с. 615.

8.Оцінка ситуації в країні, довіра до інститутів суспільства та політиків, електоральні орієнтації громадян (березень 2021p.). URL:https://razumkov.org.ua/napriamky/sotsiologichni-doslidzhennia/otsinka-sytuatsii-v-krainidovira-do-instytutiv-suspilstva-ta-politykiv-elektoralni-oriientatsii-gromadian-berezen-2021r (дата звернення: 11.07.2021).

9.Персональний склад Громадської ради при Головному управління ДФС в Івано-Франківській області. URL: http://if.sfs.gov.ua/dfs-u-regioni/gromadska-rada/personalniy-sklad-gromadskoi-radi/ (дата звернення: 10.07.2021).

10. Про національний склад населення Івано-Франківської області. URL: http://www.if.gov.ua/news/5880 (дата звернення: 07.07.2021)

11.Про поляків у Франківську і франківців у Польщі. URL:23.https://sotka.life/pro-poliakiv-u-frankivsku-ifrankivtsiv-u-polshchi-rozpovidaiut-andzhej-leush-i-mar-ia-osidach/(дата звернення:10.07.2021)

12.Про регіональну цільову програму «Духовне життя» на 2021 рік. URL: https://orada.if.ua/decision/1567-37/ (дата звернення: 01.07.2021). 
13.Ткачук Д. Г. Національні меншини як об'єкти-суб'єкти державної етнополітики. Державне управління: удосконалення та розвиток. 2020. № 7. URL: http://www.dy.nayka.com.ua/?op=1\&z=1707 (дата звернення: 07.07.2021). DOI: 10.32702/2307-2156-2020.7.53 (дата звернення: 02.07.2021).

\section{References:}

1. Bykov O. Konstytutsiino-pravovyi status natsionalnykh menshyn v Ukraini: monohrafiia. Kyiv: Int derzhavy i prava im. V.M. Koretskoho NAN Ukrainy, 2001. c. 76

2. Vasyl Vyshyvaniuk ocholyv Pochesne konsulstvo Uhorshchyny v Ivano-Frankivsku.

URL: https://kurs.if.ua/news/vasyl_vyshyvanyuk_ocholyv_pochesne_konsulstvo_ugorshchyny_ v_ivanofrankivsku_10804.html (data zvernennia: 06.07.2021).

3.V Ivano-Frankivsku za koshty YeS stvoriat «ievreiskyi» turystychnyi marshrut.

URL: https://www.ukrinform.ua/rubric-tourism/3260481-v-ivanofrankivsku-za-kosti-es-stvorat-evrejskij-turisticnijmarsrut.html (data zvernennia: 06.07.2021).

4. V Ivano-Frankivsku vidkryly "Nedilnu shkolu" z vyvchennia uhorskoi movy.

URL: https://kurs.if.ua/news/v_ivanofrankivsku_vidkryly_nedilnu_shkolu_z_vyvchennya_ugorskoi_ movy_10849.html/ (data zvernennia: 08.07.2021).

5.V Ivano-Frankivsku vidkryly uhorskyi kulturno-osvitnii tsentr. URL: https://mi100.info/2020/01/24/v-ivanofrankivsku-vidkryly-ugorskyj-kulturno-osvitnij-tsentr (data zvernennia: 09.07.2021).

6.Kovach L. Etnichni spilnoty Donbasu u suspilno-politychnomu prostori rehionu/ Naukovi zapysky Instytutu politychnykh i etnonatsionalnykh doslidzhen im. I.F.Kurasa NAN Ukrainy. 2013 / 5 (67). s. 33-45

7.Kovbasiuk Yu., Troshchynskyi V. Sotsialna i humanitarna polityka: pidruchnyk. Kyiv: NADU, 2016. c. 615.

8.Otsinka sytuatsii v kraini, dovira do instytutiv suspilstva ta politykiv, elektoralni oriientatsii hromadian (berezen 2021r.). URL: https://razumkov.org.ua/napriamky/sotsiologichni-doslidzhennia/otsinka-sytuatsiiv-kraini-dovira-do-instytutiv-suspilstva-ta-politykiv-elektoralni-oriientatsii-gromadian-berezen-2021r (data zvernennia: 11.07.2021).

9.Personalnyi sklad Hromadskoi rady pry Holovnomu upravlinnia DFS v Ivano-Frankivskii oblasti.

URL: http://if.sfs.gov.ua/dfs-u-regioni/gromadska-rada/personalniy-sklad-gromadskoi-radi/ (data zvernennia: 10.07.2021).

10. Pro natsionalnyi sklad naselennia Ivano-Frankivskoi oblasti. URL: http://www.if.gov.ua/news/5880 (data zvernennia: 07.07.2021)

11.Pro poliakiv u Frankivsku i frankivtsiv u Polshchi. URL:23.https://sotka.life/pro-poliakiv-u-frankivsku-ifrankivtsiv-u-polshchi-rozpovidaiut-andzhej-leush-i-mar-ia-osidach/(data zvernennia:10.07.2021)

12.Pro rehionalnu tsilovu prohramu «Dukhovne zhyttia» na 2021 rik. URL: https://orada.if.ua/decision/1567-37/ (data zvernennia: 01.07.2021).

13.Tkachuk D. H. Natsionalni menshyny yak obiekty-subiekty derzhavnoi etnopolityky. Derzhavne upravlinnia: udoskonalennia ta rozvytok. 2020. № 7. URL: http://www.dy.nayka.com.ua/?op=1\&z=1707 (data zvernennia: 07.07.2021). DOI: 10.32702/2307-2156-2020.7.53 (data zvernennia: 02.07.2021).

\section{Matvienkiv S. M. Public Organizations of National Minorities of Prykarpattia in the Socio-Political Life of the Region}

The article focuses on the role of national minorities in the processes of national consolidation, enrichment of national culture and the formation of civil society in Ukraine. Acting as social mediators between groups of different interests and government agencies, between civil society and the state, they focus their activities on the development of interethnic relations, the revival of national cultures, the satisfaction of their spiritual needs. For Ukraine, as for any other polyethnic state, the issue of national minorities is actual and needs constant research.

In this article is analyzed the concept of «national minorities», is explored the activities of public associations of national minorities in Ivano-Frankivsk region, is identified their role in the socio-political life of the region. In article is proved that public organizations of national minorities are mainly a means of preserving their originality and identification and they work closely with local executive bodies and local governments.

In general, Prykarpattia does not belong to the potentially conflict regions of Ukraine and is as close as possible to the average region of the country. It has been studied that the state of establishment and activity of public associations of national minorities is influenced primarily by financial support from both the states that are their historical homelands and the states in whose territory they permanently reside. It is concluded that the most active among the national minorities of Prykarpattia in public life are Poles, Hungarians and Jews. The rest of the ethnic communities did not form their own public associations either because of the small number or because there was no need for such self-organization.

Keywords: national minorities, public organizations, civil society, identity, Prykarpattia. 